\title{
POTENTIAL PRODUCTION OF DEMERSAL FISH STOCK IN THE MALACCA STRAIT OF INDONESIA
}

\author{
Purwanto ${ }^{1}$ \\ ${ }^{1}$ National Commission for Fisheries Resources Assessment, Jakarta \\ Received; July 10-2014 Received in revised from June 19-2015; Accepted June 22-2015 \\ e-mail: purwanto.pp@gmail.com
}

\begin{abstract}
Malacca Strait is one of the main fishing areas for demersal fishery in Indonesia. To support the management of that fishery, an assessment of the demersal fish stock was conducted. This study estimated that the maximum sustainable yield and the optimal catch per unit effortof demersal fishery in the Malacca Strait were about 106.8 thousand tons/year and 28.5 tons per unit of Danish seine, respectively, resulting from the operation of 3,752 Danish seines. Unfortunately, fishing effort was higher than its optimum level and the fish stock was over-exploited since 2003. To recover the demersal fish stock to its optimum level and to ensure the optimal fish production from demersal fishery in the Malacca Strait, it was necessary to reduce fishing effort at about $67 \%$ from its level in 2011.
\end{abstract}

\section{KEYWORDS: Potential production, optimal fishing effort, demersal fishery, the Malacca Strait}

\section{INTRODUCTION}

Malacca Strait is one of the main fishing ground of fishery targeting demersal fish stock in Indonesia. The Malacca Strait is located in between Peninsular Malaysia and Sumatra Indonesia.The Indonesian portion of the Malacca Strait covers an area of approximately $55,000 \mathrm{~km}^{2}$ (Dwiponggo, 1987). The potential fishery productivity of that fishing ground was high due to high primary productivity of the waters. This shallow waters was highly productive, as this area was regularly enriched by river water discharge with a high nutrient content and adequate mixing of the water column. Comparing to South China Sea and western Java Sea, the average primary production of the Malacca Strait was the highest (Doty et al., 1963). Moreover, bottom conditions of Malacca Strait are generally sandy or muddy (Dwiponggo, 1987), which is favorable for demersal fishing gear operation.

Trawl was the most productive fishing gear to utilize demersal fish stock in the shallow waters of Malacca Strait.The trawl was first introduced to Indonesian fishers at the port of Bagan Siapi-api in the late 1960s, and spread during the early 1970s throughout the Malacca Strait into the Java Sea (Unar, 1972). Favorable bottom conditions and abundant demersal fish stock resulted in viable operation and the rapid growth of the trawler fleet (Unar, 1972). Based on the result of fishery study by using catch and effort data collected from provincial fisheries offices in Aceh, North Sumatra and Riau, and information provided by trawler captains, Sujastani et al. (1976) concluded that the maximum sustainable yield (MSY) from utilizing demersal fish stock in the Malacca Strait was about 85,000 tons/year. Re-estimation of the demersal MSY was undertakenduring the workshop conducted by the South China Sea Fisheries Development and Coordinating Programme (SCS) in 1976 by taking into account stock density in deeper waters, and resulting in higher MSY level, i.e. about 120,000 tons/year (SCS, 1976).

The rapid growth of trawler operations in the Malacca Straits led to growing concern regarding overexploitation of demersal resources in that area. The development of that fishing fleet has an impact on the abundance of demersal stocks and threatened the sustainability of the resources. Based on the result of fishery assessment, Sujastani et al. (1976) reported that the demersal fish stock is fully exploited. Trawl fishing not only threatened sustainability of the resources but also resulted in serious conflict between small-scale fishers and trawl fishers. Those issues were also arising other demersal fishing grounds of Indonesia. In response, the Government of Indonesia banned trawl fishing through the promulgation of Presidential Decree No. 39 in 1980. However, other demersal fishing gears emerged after the trawl ban.

In order to formulate management policy for the demersal fishery in the Malacca Strait, the development of the fishery was evaluated by Directorate General of Fisheries in 1999. The evaluation resulted in conclusions that the demersal fish stock in the Malacca Strait was not in overexploited condition and there was possibility to increase fishing effort by $10 \%$ (Widodo et al., 1999). Unfortunately, further development of the demersal fisheryin the Malacca Strait has resulted in adverse condition of demersal fish stock. Therefore, the Minister of Marine Affairs and Fisheries stated that 
the demersal fish stock in the Malacca Straitin the condition of over-exploited (MMAF Decree No. 45/ Men/2011). In the Decree, the Minister also stated that the estimated MSY of the demersal fishery in the Malacca Strait is 82,400 tons/year.

The demersal fish stock in the Malacca Strait is a renewable resource having capability to recover when it is harvested, as long as the fishing intensity does not exceed the resource carrying capacity. An appropriate management strategy is required to sustain small pelagic fish stock and to optimize economic benefit from the utilization of this fishery resource (Article 6 of the Act no. 31 of 2004 on Fisheries). To improve management strategy for demersal fish stock in the Malacca Strait, it is necessary to assess its fishery resource in order to update information on the potential production of the fishery. The results of the assessment will also be required to develop a policy to manage logistic of fish processing industry in Indonesia. The demersal fish stock and the demersal fishery in the Malacca Strait have been assessed, and the result of the assessment is presented in this paper.

\section{MATERIALS AND METHODS Model and Method of Analysis}

Analysis was undertaken on the basis of the surplus production models. Two models, namely Schaefer $(1954,1957)$ and Fox $(1970,1975)$ models were evaluated. The equations of the models are as follows:

$$
\begin{aligned}
& Y=a \cdot E-b \cdot E^{2} \ldots \ldots \\
& Y=c \cdot E \cdot \exp (d \cdot E)
\end{aligned}
$$

where:

$$
\begin{array}{ll}
E & =\text { fishing effort; } \\
Y & =\text { Yield or total catch; }
\end{array}
$$

$a, b, c$ and $d=$ coefficients of the production functions.

The value of coefficients $a, b, c$ and $d$ of the production functions were estimated by least square method using the following catch per unit effort functions (Equations (3) \& (4). The coefficient of determination and the value of t-statistic were used to choose the model that was statistically appropriate for this study.

$U=a-b . E$

$U=c \cdot \exp (d . E)$ where: $U=$ catch per unit effort (CPUE).

Mean while, the level of fishing effort was estimated as follows:

$E=h / U$

As $U=Y / E$, CPUE indicates the actual productivity of fishing effort or fishery. Furthermore, CPUE also indicates the abundance of fish stock as $Y=q . E . x$ and $U=q . x$.

\section{Data}

Analysis for this paper used statistical data of the demersal fishery in the Malacca Strait during year 2003-2011 published by DGCF (2004-2012). The data consisted of the number of demersal Danish seines, the quantity of fishes caught by the Danish seine fishery, and the demersal fish production. The number of Danish seines and the quantity of their catches were used to estimate the catch per Danish seine unit. Mean while, the demersal fish production and the catch per Danish seine unit were used to estimate the level of fishing effort.

\section{RESULTS AND DISCUSSION Results}

The relationships between the catch per unit effort $(U)$ and the fishing effort $(E)$ in the demersal fishery of the Malacca Strait were significantly represented by the following equations:

$$
\begin{gathered}
U=53.70549-0.006324_{\star} E ; R^{2}=0.81 \\
(10.771)^{\star * *} \\
(5.463)^{\star * *}
\end{gathered}
$$

$$
U=77.40154 \exp (-0.0002665, E) ; \mathrm{R}^{2}=0.89
$$

$$
(7.510)^{\star \star \star} \quad(6.881)^{\star \star \star}
$$

Note: ${ }^{* *} t$-statistics in the parentheses are significant at $\mathrm{P}<0.001$.

The results of the statistical analyses presented as Equations (6) and (7) show that both models fit to the data used in this study. The independent variable of those two models was significant at $P<0.001$. However, Equation (7) has higher coefficient of determination $\left(R^{2}\right)$. On the basis of the coefficient of determination $\left(R^{2}\right)$ of Equation (7), about $89 \%$ of the variation in the dependent variable of the equation can be explained by the variation of the independent variable. Therefore, Equation (7) was used in this study.

Based on Equation (7), the productivity of fishing vessels in the Malacca Strait demersal fishery, as 
indicated by the catch per unit effort, decreased with increasing fishing effort (Figure 1A). Mean while, the catch or yield increased to the maximum level with increasing fishing effort (Figure 1B). After attaining the maximum level, i.e. maximum sustainable yield (MSY), increasing fishing effort resulted in lower catch. The relationship between the quantity of catch and fishing effort in the Malacca Strait demersal fishery was represented by the following equation:

$U=77.40154, E, \exp (-0.0002665, E)$.
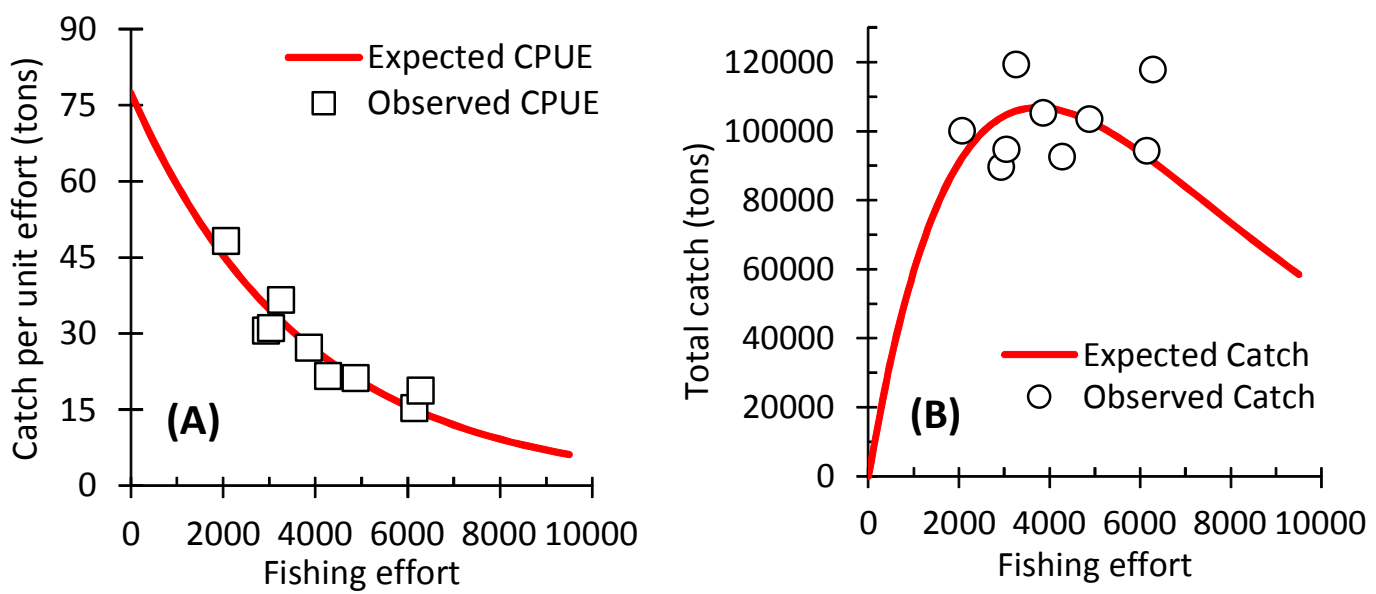

Figure 1. The relationships between fishing effort and: $(A)$ catch per unit effort, and $(C)$ total catch, in the demersal fishery of the Malacca Strait.

Based on Equations (7) and (8), the estimated optimal levels of fishing effort, total catch and catch per unit effort of the demersal fishery in the Malacca Strait are presented in Table 1. The MSY was about 106.8 thousand tonnes/year resulting from the operation of 3,752 Danish seines, which was the biologically optimal level of fishing effort $\left(E_{\mathrm{MSY}}\right)$. Mean while, optimal catch per unit effort $\left(U_{\text {MSY }}\right)$ was about 28.5 tonnes per unit of Danish seine.

Comparing the fishing effort level and the fish stock abundance, as indicated by the catch per unit effort, with their estimated optimal levels, the development of demersal fishery in the Malacca Strait during the period of assessment (2003-2011) can be divided into two segments of fishery development. The first segment, during 2003-2006, the fishery was utilizing the demersal fish stock in the Malacca Strait at the level of effort lower than the $E_{\mathrm{MSY}}$, and the abundance of that fish stock was at a safe level, as indicated by its CPUE that was higher than $U_{\text {MSY }}$ (Figures $1 \mathrm{~A}$ \& 2A; Table 1; Appendix 1). The second segment, i.e. 2007-2011, the fishery was over-exploiting the demersal fish stock, and the fish stock was in the over-exploited condition, as indicated by its CPUE that was lower than $U_{\text {MSY }}$.

Table 1. Estimated fishing effort, total catch and catch per unit effort of the demersal fishery in the Malacca Strait in 2003, 2007 and 2011, and their estimated biological optimal levels.

\begin{tabular}{llrrrr}
\hline \multirow{2}{*}{ Units } & \multicolumn{3}{c}{ Status of fishery } & \multirow{2}{*}{ Biological } \\
\cline { 3 - 4 } & & Year & Year & Year & optimal level \\
\hline Fishing effort & Number of Danish seines & $\mathbf{2 0 0 3}$ & $\mathbf{2 0 0 7}$ & $\mathbf{2 0 1 1}$ & \\
Total catch & 1,000 tonnes/year & 105.8 & 1066 & 6,282 & 3,752 \\
Catch per unit effort & tonnes/effort & 32.5 & 27.7 & 14.1 & 106.8 \\
\cline { 3 - 4 } & & & & & 28.5 \\
\hline
\end{tabular}

Those conditions can be shown from plotting the relative fishing effort, i.e. fishing effort at each year divided by optimal fishing effort level, and relative abundance of stock, indicated by estimated stock abundance index at each year divided by optimal stock abundance index (Figure 2B). The first segment was in quadrant-1 (Q1) where $E / E_{\mathrm{MSY}}<1$ and $U / U_{\mathrm{MSY}}>1$, while the second segment was in quadrant-3 (Q3) where $E / E_{\mathrm{MSY}}>1$ and $U / U_{\mathrm{MSY}}<1 . \ln 2011, E / E_{\mathrm{MSY}}=$ 1.67 and $U / U_{\text {MSY }}=0.66$. These figures indicate that fishing effort in 2011 was $67 \%$ higher than the optimum level, while the demersal fish biomass in that year was $34 \%$ lower than the optimum level. 

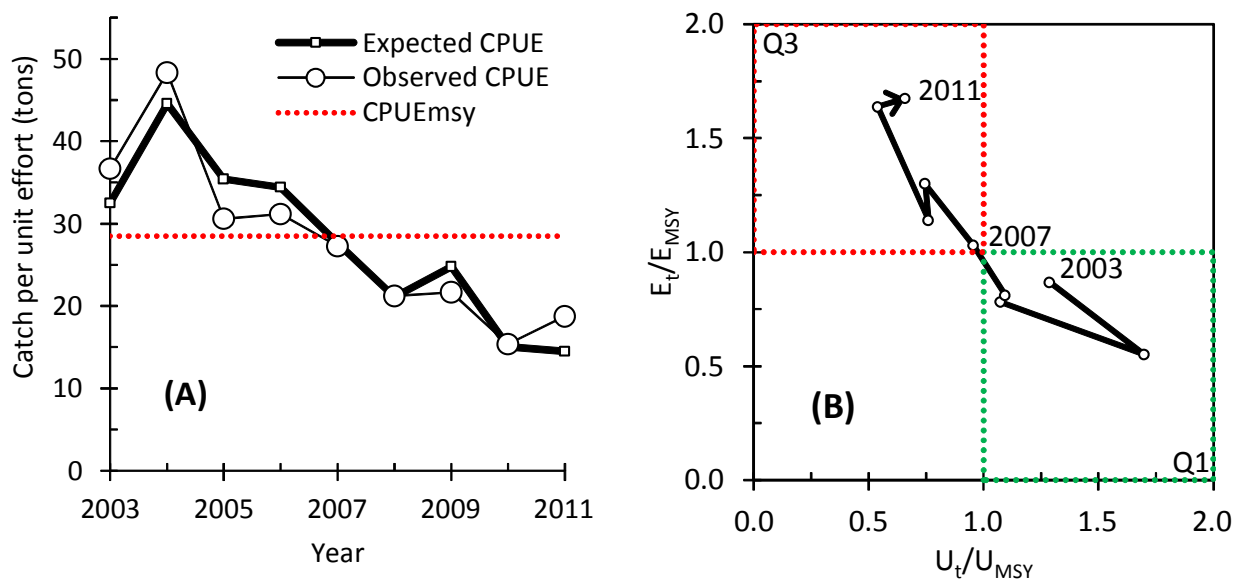

Figure 2. Development of $(A)$ catch per unit effort (CPUE) of the demersal fishery, and (B) relative fishing effort of the demersal fishery and relative abundance of the demersal fish stock, as indicated by relative CPUE, in the Malacca Strait, 2003-2011.

\section{Discussion}

The significant relationship and the high correlation between the catch per unit of Danish seine and fishing effort calculated on the basis of the statistical data on demersal fishery production (Equation 7), show the possibility to use the statistical data collected and published by DGCF in the assessment of demersal fishery in the Malacca Strait (Figure 1; Table 1). This study estimated that the MSY of demersal fishery in the Malacca Strait was about 106.8 thousand tons/year. This estimated MSY level was higher than that estimated by Sujastani et al. (1976), i.e. about 85,000 tons/year, and that stated in the MMAF Decree No. $45 / \mathrm{Men} / 2011$, i.e. about 82,400 tonnes/year, but lower than that resulting from the Workshop conducted by the SCS in 1976 (SCS, 1976), i.e. about 120,000 tons/year. However, it was suggested to use the MSY level resulted from this study as it used the latest data, which represented the last fishery conditions.

The result of this study that covered years 20032011 indicated that the demersal fishery was overexploiting the demersal fishstock in the Malacca Strait, and the fish stock was in the over-exploited condition since 2007 (Figure 2). This result supported the MMAF Decree no 45/Men/2011, stating that the demersal fish stock in that waters was in the over-exploited condition. This study also shows that the demersal fish stock has not considerably recovered from overexploitation yet.

As the consequence of fishery resource overexploitation, the production of demersal fishes and the productivity of demersal fishery were sub-optimal (Figure 1). There was no latest assessment of the economic consequences of the fishery over-exploiting the demersal fish stock in the Malacca Strait of Indonesia. However, bio-economic studies of the demersal fishery in the Malaysian portion of the Malacca Strait (Tai, 1996) and in the Java Sea (Purwanto, 2003) and a bio-economic study of shrimp fishery in the Arafura Sea (Purwanto, 2008 \& 2013) show that the economic benefits of the fisheries was sub-optimal when demersal fishery resources were over-exploited.

Unfortunately, the existence of illegal and unreported fishing practices may result in a serious problem in the validity and the reliability of the capture fisheries statistical data that could result in poor quality of fishery assessment as those two fishing practices resulted in incomplete and biased data and information on fisheries. Dwiponggo (1987) reported the discrepancy between the number of demersal fishing vessels operating in the Malacca Strait recorded in the field and the one reportedby the Directorate General of Fisheries. The discrepancy may reflect the existence of unlicensed fishing vessels. Illegal fishing was reported to exist in the Malacca Strait (Purwanto, 2009). Those problems also happened, for example, in the Arafura Sea fishery (Purwanto, 2014a,b). To ensure the quality of the assessment, proper estimation of unreported fishing activity should be undertaken and taken into account during data collection and processing in order to have valid and reliable statistical data. Unfortunately, there was no information on the magnitude of illegal and unreported fishing targeting demersal fishes in the Malacca Strait so far.

However, as stated by FAO (1995 \& 2011), the absence of adequate information should not be used as a reason for postponing or failing to take measures 
to manage demersal fishery and to conserve demersal stock in the Malacca Strait. As agreed by FAO Members, this precautionary approach should be applied widely to conservation, management and exploitation of living aquatic resources in order to protect them and preserve the aquatic environment, taking account of the best scientific evidence available (FAO, 1995 \& 2011). Historically, the implementation of precautionary approach to protect the environment was agreed by the participants of the United Nations Conference on Environment and Development held in 1992 (UN, 1992), and was reaffirmed in the World Summit on Sustainable Development in 2002 (UN, 2002). Furthermore, a commitment to effectively apply the precautionary approach in the management of activities having an impact on the marine environment was expressed by the Delegation of Nations to the World Summit on Sustainable Development in 2012 (UN, 2012).

While collecting more information for the management of fishery, it is necessary to control fishing effort to the optimal level to ensure the optimal fish production and the optimal economic benefits from demersal fishery in the Malacca Strait. Based on the result of the study, as presented in Figure $2 \mathrm{~B}$, the fishing effort of demersal fishery in the Malacca Strait should be reduced about $67 \%$ from its level in 2011 in order to recover the demersal fish stock in that fishing ground to its optimum level. Reducing effort by decommissioning of some fishing vessels would be difficult to be conducted as it would be opposed by fishers. Purwanto et al. (1988) evaluated and showed that the fishing effort could be decreased to the optimal level by reducing fishing trips. However, further assessment should be undertaken to formulate an appropriate strategy to reduce fishing effort accepted by fishers.

\section{CONCLUSION}

The MSY and the optimal catch per unit effort $\left(U_{\text {MSY }}\right)$ of demersal fishery in the Malacca Strait were about 106.8 thousand tons/yearand 28.5 tons per unit of Danish seine, respectively, resulting from the operation of 3,752 Danish seines; The demersal fishery was over-exploiting the stock of demersal fishes in the Malacca Strait, and the fish stock was in the overexploited condition since 2007.
Therefore, it is suggested to reduce the fishing effort of demersal fishery in the Malacca Strait in order to recover the demersal fish stock in that fishing ground to its optimum level. However, further assessment should be undertaken to formulate an appropriate strategy to reduce fishing effort accepted by fishers.

\section{REFERENCES}

Doty, M.S., R.E. Soeriaatmadja \& A. Soegiarto. 1963. Observation on the primary productivity of Northwestern Indonesian Waters. Mar. Res. Indonesia 5: p. 1-25.

Directorate General of Capture Fisheries (DGCF). 2004-2012. Statistik Perikanan Indonesia. DGCF, Jakarta.

Dwiponggo, A. 1987. Indonesian marine fisheries resources. p. 10-63. In C. Bailey, A. Dwiponggo \& F. Marahudin (eds.) Indonesian marine capture fisheries. ICLARM Studies and Review 10. 196 pp.

Food and Agriculture Organisation (FAO). 1995 \& 2011. Code of Conduct for Responsible Fisheries. FAO, Rome. 41 pp.

Fox, W.W. 1970. An exponential surplus yield model for optimizing exploited fish populations. Trans. Amer. Fish. Soc., 1970 (1): p. 80-88.

Fox, W.W. 1975. Fitting the generalized stock production model by least-squares and equilibrium approximation. Fishery Bulletin 73 (1): p. 23-37.

Minister of Marine Affairs and Fisheries (MMAF) Decree (Keputusan Menteri Kelautan dan Perikanan) nomor 45/Men/2011 tentang Estimasi Potensi Sumberdaya Ikan di Wilayah Pengelolaan Perikanan Negara Republik Indonesia.

Presidential Decree No. 39 Year 1980.

Purwanto. 2003. Status and management of the Java Sea fisheries. 793-832. In G. Silvestre, L. Garces, I. Stobutzki, M. Ahmed, R. A. Valmonte-Santos, C. Luna, L. Lachica-Aliño, P. Munro, V. 
Christensen \& D. Pauly (eds.) Assessment, Management, and Future Directions for Coastal Fisheries in Asian Countries. World Fish Center Conference Proceeding 67: 1120 pp.

Purwanto. 2008. Resource rent generated in the Arafura shrimp fishery. Final Draft. Prepared for the World Bank PROFISH Program. Washington. D.C. 29 pp.

Purwanto. 2009. Strategi penanggulangan illegal fishing dan optimalisasi pemanfaatan sumberdaya ikan guna mendukung good governance dalam rangka mensukseskan pembangunan nasional. Kertas Karya Perorangan. PPSA XVI, Lembaga Ketahanan Nasional RI, Jakarta. 112 hal.

Purwanto. 2013. Status perikanan udang di Laut Arafura ditinjau dari kajian bio-ekonomi. Jurnal Penelitian Perikanan Indonesia, Vol. 19 (4): 227234.

Purwanto. 2014a. Estimasi produksi udang yang tidak dilaporkan dari kegiatan penangkapan di Laut Arafura.

Purwanto. 2014b. Biomasa, produktivitas kapal penangkap dan potensi produksi ikan demersal di Laut Arafura.

Purwanto, K.H. Nitimulyo \& T. Jatileksono. 1988. Optimisasi ekonomi penangkapan udang di pantai selatan Jawa Tengah dan sekitarnya. Gadjah Mada University Graduate Research Publication 1(4): 557-567.

Schaefer, M.B. 1954. Some aspects of the dynamics of populations important to the management of commercial marine fisheries. Bulletin of the InterAmerican Tropical Tuna Commission 1 (2): p. 2756.
Schaefer, M. B. 1957. A study of the dynamics of the fishery for yellowfin tuna in the eastern tropical Pacific Ocean. Bulletin of the Inter-American Tropical Tuna Commission 2 (6): p. 247-268.

Sujastani, T., P. Martosubroto \& D. Pauly. 1976. A review of the demersal fishery of Indonesia in the Malacca Strait, based on recent surveys and catch and effort data, p. 23-47. In Report of the Workshop on the Fishery Resources of the Malacca Strait, 29 March-2 April 1976, Jakarta. Part I. SCS/GEN/76/2. South China Sea Fisheries Development and Coordinating Programme, Manila.

South China Sea Fisheries Development and Coordinating Programme (SCS). 1976. Report of the Workshop on the Fishery Resources of the Malacca Strait, Part II. 29 March-2 April 1976, Jakarta. SCS/GEN/76/6.85p. South China Sea Fisheries Development and Coordinating Programme, Manila.

Tai, S.Y. 1996. Optimal bioeconomic exploitation of the demersal fishery in Northwest Peninsular Malaysia. Pertanika J. Soc. Sci. \& Hum., 4: p. 65-76.

Unar, M. 1972. Tinjauan perikanan udang di Indonesia dan perkembangannya sekarang. Laporan Penelitian Perikanan Laut, No. 1: 1-26.

United Nations (UN). 1992. Report of the United Nations Conference on Environment and Development, Rio de Janeiro, 3-14 June 1992 Annex I: Rio Declaration on Environment and Development.

United Nations (UN). 2002. Report of the World Summit on Sustainable Development, 
Johannesburg, South Africa, 26 August-4 September 2002.

United Nations (UN). 2012. Report of the United Nations Conference on Sustainable Development, Rio de Janeiro, Brazil, 20-22 June 2012.
Undang Undang (Act) No. 31 Tahun 2004 tentang Perikanan.

Widodo, J., Purwanto \& J. Martoyo. 1999. Kajian pengoperasian pukat ikan di perairan Zona Ekonomi Eksklusif Indonesia (ZEEI) Selat Malaka. Direktorat Jenderal Perikanan, Departemen Pertanian, Jakarta. 75 pp. 
Ind.Fish.Res.J. Vol.21 No.1 June 2015 : 45-52

Appendix 1. Total catches, catch per unit fishing effort and fishing effort of the demersal fishery in the Malacca Strait, $2003-2011$.

\begin{tabular}{cccc}
\hline Year & Catch (tons) $\mathbf{1}^{-}$ & CPUE (tons) $\mathbf{1}^{-}$ & Effort ${ }^{\mathbf{2} .}$ \\
\hline & $Y$ & $U$ & $E$ \\
\hline 2003 & 119,334 & 36.65 & 3,256 \\
2004 & 100,087 & 48.34 & 2,070 \\
2006 & 89,687 & 30.58 & 2,933 \\
2007 & 94,775 & 31.15 & 3,042 \\
2008 & 105,215 & 27.25 & 3,862 \\
2009 & 103,522 & 21.22 & 4,878 \\
2010 & 92,646 & 21.67 & 4,276 \\
2011 & 94,366 & 15.35 & 6,146 \\
& 117,833 & 18.76 & 6,282 \\
\hline
\end{tabular}

Remarks:1. Source of data: DGCF (2004-2012); $\underline{2} \cdot E=h / U$. 